\title{
'No more Hoares to Paris': British foreign policymaking and the Abyssinian Crisis, 1935
}

\author{
ANDREW HOLT
}

\begin{abstract}
Italy's invasion of Abyssinia in October 1935 prompted a major European crisis. This article applies the main theories of foreign policy analysis to the British Government's handling of this crisis. It argues that bureaucratic politics existed, but had little impact on outcomes. Domestic politics had more influence, but did not provide detailed instructions on how to act. The perceptions of key actors, informed by reasoned judgement, determined this. Fears of the threat posed by rival states coalesced with concerns about Britain's own military weakness, leading decision-makers to emphasise the need to act in tandem with France. British policy was therefore motivated by the tension between the public's desire to see action against Italy and the Government's wish to minimise any breach with her allies. These findings highlight the weaknesses of the bureaucratic politics model and show how domestic politics can affect foreign policy outcomes. They also demonstrate the interaction between rational analysis defined in terms of reasoned judgement, and actors' perceptions. It is thus argued that benefits are to be gleaned from combining these theories.
\end{abstract}

Andrew Holt is currently a University Teacher in the Department of Politics, History and International Relations, Loughborough University. He received his $\mathrm{PhD}$ from The University of Nottingham and his work has appeared in Diplomacy \& Statecraft.

On 3 October 1935, Italian troops marched into the East African state of Abyssinia (now known as Ethiopia). This was not Italy's first attempt to seize control of the country. An earlier endeavour ended with defeat at Adowa on 1 March 1896, leaving what the Italian nationalist poet Gabriele D'Annunzio described as a 'shameful scar' on the recently unified nation. ${ }^{1}$ Benito Mussolini, Fascist Dictator of Italy from 1922, was determined to avenge this perceived humiliation. After a skirmish at Wal-Wal on the border between Abyssinia and Italian Somaliland in December 1934, he seized his opportunity In the process, Mussolini plunged Europe into crisis. Britain's interest in Abyssinia was limited. She required the safety of Lake Tsana's headwaters - its tributary the Blue Nile was an important river for the British colony of Sudan - and there was also some concern that an Italian conquest could damage trade. Nevertheless, British policymakers, encouraged by their French counterparts, prioritised maintaining friendly relations with Italy as a means of presenting a unified front against German revisionism. ${ }^{2}$ Unfortunately for Britain, Italian demands forced Abyssinia to appeal to the

\footnotetext{
${ }^{1}$ Quoted in Norman Rose, Vansittart: Study of a Diplomat (London: Heinemann, 1978), p. 156.

${ }^{2}$ See 'The Maffey Report', Documents on British Foreign Policy [hereafter DBFP], Vol. XIV, Appendix II (18 June 1935).
} 
League of Nations. Thus, when the League declared the Italian invasion to be an act of aggression, Britain and France, as the organisation's leading members, faced a dilemma: to betray League principles or to alienate a valuable continental ally.

The policy that emerged from this impasse pleased no one. The League imposed sanctions on Italy, but the exclusion of restrictions on oil rendered them largely ineffectual. The British Cabinet, meanwhile, vacillated. With a General Election called for 14 November 1935, Prime Minister Stanley Baldwin spoke of his support for the League. In December, however, Sir Samuel Hoare, the Foreign Secretary, stopped off in Paris en route to a much-needed holiday in Switzerland. The solution that emerged from these talks, proposed in conjunction with French Premier Pierre Laval, put two thirds of Abyssinia under Italian control - seemingly more than she had yet conquered. The Cabinet approved the plan, then, in the face of a public outcry, repudiated it, forcing Hoare's resignation.

According to A. J. P. Taylor, 'No one knows why the British government took the line they did; probably they did not know themselves'. ${ }^{3}$ This article endeavours to explain why. Drawing from the field of foreign policy analysis (FPA), it assesses the relative influence of bureaucratic politics, domestic politics and psychological factors on decision-makers, focusing on attitudes to the key issues of sanctions and the Hoare-Laval Plan. The major decision-makers receive particular attention. In June 1935, Baldwin became Prime Minister for the third time - though he was the effective leader of the Government before then - whilst Hoare replaced Sir John Simon as Foreign Secretary. The young Anthony Eden was a Foreign Office (FO) minister, latterly as Minister for League of Nations Affairs with a Cabinet seat. The views of the Cabinet as a whole also merit examination, as do those held by prominent civil servants within the Foreign Office. Given his dominance, this is especially true of Sir Robert Vansittart, the Permanent Under-Secretary.

The Abyssinian Crisis provides an excellent opportunity test the strengths and weaknesses of the main branches of foreign policy analysis theory. Theorists often tend to focus on more recent events, but using an example from the 1930s allows for greater historical perspective and provides the benefit of readily available documentary evidence. Contemporary policymakers recognised the Abyssinian issue as being of the utmost importance. Indeed, critics such as Eden regarded the attempts to pacify Italy as one of the first acts of 'appeasement', with some holding the view that a strong line against Mussolini could have discouraged later German aggression and therefore even prevented World War II. The nature of the crisis itself also makes it eminently suitable as a case study. As policy developed over a relatively long period of time, it possible to see how preferences evolved. Two specific features make it especially interesting. Vansittart was an extremely powerful civil servant who had strong, well-defined views, making an analysis of the role of the bureaucracy particularly relevant. In addition, the British public took a keen interest in the crisis and Baldwin's decision to hold an election as events reached their crescendo enhanced the importance of popular opinion.

Before the article addresses the above issues, an introductory analysis of the FPA literature is necessary. The rational actor, bureaucratic politics and psychological approaches all contain useful insights, but also serious defects. It is better therefore to use them in concert. The following section builds on these theories in

\footnotetext{
${ }^{3}$ A. J. P. Taylor, The Origins of the Second World War, new edition (London: Penguin, 1964), p. 121.
} 
order to determine the primary influences on British foreign policy in the 1930s. It argues that although domestic political factors influenced policymakers, the main actors deciding policy were certain key office holders and top FO officials. Having established this, the article then focuses on how British policy emerged with reference to these theories. Bureaucratic politics is examined first. It shows that while bureaucratic politics did exist within the British policymaking machine, it had little influence on outcomes. The article then goes on to analyse domestic politics, finding that despite its contradictions, public opinion encouraged the Government to act against Italy when it might otherwise not have done so, and forced it to repudiate the Hoare-Laval Plan. Finally, psychological influences and perceptions of other actors are considered, revealing that perception combined with rational analysis of intentions and threats, led to a reliance on French support. The conclusion assesses the implications of these findings for the aforementioned FPA theories.

\section{Foreign policy analysis}

Although individuals or small groups of ministers and officials are usually responsible for decision-making, there are many complex influences upon them. In explaining these influences, the rational actor model predominated for many years. Changes in FPA began in the 1970s with the emergence of two new approaches. The first of these concentrated on structural influences on policymakers. Graham T. Allison initially put forward two alternative models - organisational processes and bureaucratic politics - whilst others emphasise the importance of public opinion. The second approach examined the psychology of decision-makers. Irving Janis produced a study showing how 'groupthink' can occur. In contrast, Robert Jervis focused on perception. From this group of psychology-based theories, history as an influence on decision-makers spawned its own literature.

The traditional approach to FPA is the rational actor model. This assumes that an action represents a rational, value maximising choice. However, it oversimplifies the decision-making process by failing to account for the potential for conflict between the interests of the individual and those of the state. ${ }^{4}$ Martin Hollis and Steve Smith thus put forward a more relevant definition of rationality based on reasoned judgement rather than actors pursuing unquestioned aims. ${ }^{5} \mathrm{~A}$ second criticism, that as emotional beings, people find it impossible to ignore completely their values, wishes and beliefs, is more difficult to overcome. ${ }^{6}$ Finally, the model also neglects the impact of organisations on decision-makers.

${ }^{4}$ Jeremy L. Richardson, Crisis Diplomacy: The Great Powers Since the Mid-Nineteenth Century (Cambridge: Cambridge University Press, 1994), p. 15.

5 Martin Hollis and Steve Smith, 'Roles and Reasons in Foreign Policy Decision Making', British Journal of Political Science, 16:3 (1986), p. 283. See also, Richardson, Crisis Diplomacy, pp. 14-5, 236, 357, 361.

${ }^{6}$ Hollis and Smith, 'Roles and Reasons', p. 278; Richard Ned Lebow, Between Peace and War: The Nature of International Crisis (Baltimore: Johns Hopkins University Press, 1981), pp. 101-3, 107; Thomas M. Mongar, 'Personality and Decision-Making: John F. Kennedy in Four Crisis Decisions', Canadian Journal of Political Science, 2:2 (1969), p. 225. 
Graham Allison's work marked a breakthrough in FPA. His organisational processes model, later renamed organisational behaviour, holds that standard rules and procedures limit available choices and determine the actions of a government. ${ }^{7}$ Information reaches decision-makers via a series of intermediaries enabling distortion to occur en route, with bureaucrats able to structure issues to elicit the desired response from decision-makers. ${ }^{8}$ Allison's more famous bureaucratic politics model, later endorsed by Morton Halperin, contends that outcomes result from bargaining between leaders and organisations. The bureaucratic position of a decision-maker shapes their goals and actors' relative political weights can be decisive. ${ }^{9}$ This model contains serious flaws. First, positions do not determine all disagreements even in Allison's chosen case of the Cuban Missile Crisis. ${ }^{10}$ Similarly, people can hold numerous roles as well as official positions, potentially leading to conflict between them. The model also underestimates the importance of the individual actor, especially leaders, and falsely assumes that departmental interests are obvious. Moreover, the organisational perspective becomes less important in a crisis, when non-routine issues are involved. Governments tend to behave as unitary actors in such situations. ${ }^{11}$ Finally, Allison based his models entirely on the American policymaking system. The differences between bureaucratic structures thus further weaken the general explanatory power of the models.

Public opinion is a more widely applicable structural variable. There has been a traditional acceptance of the primacy of domestic circumstances, whereby the desire to retain power dominates decisions. ${ }^{12}$ More recent research has challenged this, however. For example, a study by Thomas Risse-Kappen found that leaders often make decisions without public support. Although the extent to which the mass (as opposed to 'attentive') public is interested in foreign affairs is often under-rated, domestic issues remain more important to most people. ${ }^{13}$ The key factor, therefore, is the level of public passion about a particular issue, which is likely to increase in a crisis.

${ }^{7}$ Graham Allison and Philip Zelikow, Essence of Decision: Explaining the Cuban Missile Crisis, 2nd edition (New York: Longman, 1971), pp. 164-5.

8 Joseph Frankel, 'Towards a Decision-Making Model in Foreign Policy', Political Studies, 7:1 (1959), p. 8; Morton H. Halperin, Bureaucratic Politics and Foreign Policy (Washington, DC: Brookings Institution, 1974), p. 116. See also, Zeev Maoz, 'Framing the National Interest: The Manipulation of Foreign Policy Decisions in Group Settings', World Politics, 43:1 (1990), pp. 77-110.

${ }^{9}$ Allison and Zelikow, Essence of Decision, pp. 256-8; Halperin, Bureaucratic Politics, p. 99.

${ }^{10}$ Robert Jervis, Perception and Misperception in International Politics (Princeton: Princeton University Press, 1976), pp. 26-7; Hollis and Smith, 'Roles and Reasons', p. 283. See also, Edward Rhodes, 'Do Bureaucratic Politics Matter? Some Disconfirming Findings from the Case of the US Navy', World Politics, 47:2 (1994), pp. 30, 32, 39.

${ }^{11}$ Hollis and Smith, 'Roles and Reasons', pp. 275-7; Jonathan Bendor, and Thomas H. Hammond, 'Rethinking Allison's Models', American Political Science Review, 86:2 (1992), p. 315; Lebow, Between Peace and War, pp. 155-6; Jeffrey Record, Making War, Thinking History: Munich, Vietnam, and Presidential Uses of Force From Korea to Kosovo (Annapolis, Maryland: Naval Institute Press, 2002), p. 2; Richardson, Crisis Diplomacy, p. 253.

12 Frankel, 'Towards a Decision-Making Model', p. 5; Jervis, Perception and Misperception, p. 387. See also, Lebow, Between Peace and War, p. 305.

13 Thomas Risse-Kappen, 'Public Opinion, Domestic Structure and Foreign Policy in Liberal Democracies', World Politics, $43: 4$ (1991), pp. 480-1; James Barber, Who Makes British Foreign Policy? (Milton Keynes: Open University Press, 1976), pp. 7-8; David Vital, The Making of British Foreign Policy (London: Allen and Unwin 1968), pp. 72-5. Cf. William Wallace, The Foreign Policy Process in Britain (London: Allen and Unwin, 1977), p. 88. 
The second line of attack on the rational actor paradigm emanates from psychological research. Irving Janis found that within a group, cohesiveness can cause greater adherence to group norms, with groups more prone to risk taking and the dehumanising stereotyping of rivals. ${ }^{14}$ Janis's analysis is persuasive, though it negates the impact of conflicting personal interests and of dominant personalities. The most salient work in this area, however, looks at the individual policymaker. Robert Jervis and Ole R. Holsti both note the importance of perceptions. Actors base their behaviour on how they think others will act. ${ }^{15}$ Misperception is most common in predicting intentions, where relevant data is harder to acquire. Mirror imaging, assuming an adversary will act identically to how you yourself would act if in the same position, can influence this. National self-images can also affect policy outcomes, with policymakers feeling that they must act in accordance with their country's reputation and values. Furthermore, individual experience and belief systems can influence judgements. ${ }^{16}$ There is no agreement on how perceptions form. Whilst Richard Ned Lebow, and Janis and Leon Mann hold that people see what they want to see (the motivational hypothesis), Jervis argues that people see what they expect. ${ }^{17}$ Given the evidence in support of both hypotheses, it is likely that each applies in different circumstances. Psychological approaches are difficult to criticise on the theoretical level - they require research to substantiate or disprove them - yet they struggle to explain the frequency with which misperception is likely to occur.

History, one particular influence on perception, has generated a literature of its own. Policymakers often use it to reinforce a chosen course of action, though but it can shape views too. ${ }^{18}$ In general, history has promoted poor reasoning. Analogies associated with disasters have the most impact and decision-makers often fail to consider a sufficiently wide range of comparative examples. In addition, the lessons learned are often superficial and over-generalised. Nevertheless, Jeffrey Record plays down the impact of history, noting that 'Analogies influence, but do not dictate, decisions'. ${ }^{19}$

No one perspective alone can provide a satisfactory explanation of policymaking. All have distinct strengths and weaknesses. The rational-actor model remains powerful if considered in terms of reasoned judgement, but is too simplistic to use alone. Most are too insular - focusing on one particular influence at the expense of others. This is most prevalent in Allison's work, which

${ }^{14}$ Irving L. Janis, Groupthink: Psychological Studies of Policy Decisions and Fiascoes (Boston: Houghton Mifflin, 1982), pp. 3-5.

15 Jervis, Perception and Misperception, pp. 32, 68; Ole R. Holsti, 'Individual Differences in "Definition of the Situation",, Journal of Conflict Resolution, 14:3 (1970), pp. 303-34.

${ }^{16}$ Richardson, Crisis Diplomacy, p. 268; Lebow, Between Peace and War, pp. 195-202; Steve Smith, 'Belief Systems and the Study of International Relations', in Richard Little and Steve Smith (eds), Belief Systems and International Relations (Oxford: Oxford University Press, 1988), p. 12; Jervis, Perception and Misperception, p. 187.

${ }^{17}$ Lebow, Between Peace and War, pp. 224-8; Irving L. Janis and Leon Mann, Decision Making: A Psychological Analysis of Conflict, Choice, and Commitment (New York: Free Press, 1977); Jervis, Perception and Misperception, p. 406. See also, pp. 369-72, 380; Richard E. Neustadt and Ernest R. May, Thinking in Time: The Uses of History for Decision-Makers (New York: Free Press, 1986), p. 235.

18 Record, Making War, Thinking History, p. 3; Jervis, Perception and Misperception, p. 17.

19 Ernest R. May, "Lessons" of the Past: The Use and Misuse of History in American Foreign Policy (New York: Oxford University Press, 1973), pp. ix-xii; Jervis, Perception and Misperception, pp. 271, 281-2; Record, Making War, Thinking History, pp. 129, 155-6, 164. 
overemphasises bureaucratic procedures and official positions. Allison's models also understate the influence of the actor and are difficult to apply to systems outside Washington, weakening their explanatory power. The impact of the public varies depending on their interest in the issue, whilst 'groupthink' and especially actors' perceptions can also be crucial. The past, too, can influence decisionmakers, but is singly insufficient for action. A combination of these approaches should thus yield better results, making assessing the relative bearing of each factor the key difficulty. ${ }^{20}$ This is likely to vary across countries, as systems, values and experiences differ. Before analysing the Abyssinian Crisis using the insights provided by these theories, an examination the British foreign policymaking system is therefore necessary.

\section{Foreign policymaking in Britain}

Britain had a worldwide network of interests in the 1930s. Her foreign policymaking process was 'perhaps more complex than any other European power'. ${ }^{21}$ Although the Foreign Office was formally responsible handling this complexity, a number of actors were involved in the shaping of British foreign policy. There are four schools that contest which were most influential. The pluralist and public control perspectives focus on the role of the public and pressure groups respectively. A third approach considers formal office holders, whilst, finally, the departmental negotiated order school considers other departments and civil servants. Each of these approaches provides some insight into the making of British foreign policy.

The first two approaches emphasise the influence of the public, both indirect and direct. The pluralist perspective concentrates on political parties and pressure groups. Political parties had only limited influence in the mid-1930s. They contained splits, whilst the National Government was particularly strong. The influence of Parliament in foreign affairs is also usually slight. ${ }^{22}$ On the other hand, there were a large number of foreign policy pressure groups Britain. The League of Nations Union, for example, had 500,000 members. Despite this however, their opportunities to influence policy were limited, as much was decided within the Foreign Office. Pressure groups thus exerted influence only as an expression of public opinion. The public control perspective attributes greatest significance to public opinion directly. ${ }^{23}$ William Wallace argues that 'no government can afford to ignore the domestic context of foreign policy' and the impending election forced the Government to pay particular attention to public opinion. ${ }^{24}$ Nevertheless, although significant, public opinion did not prescribe detailed policy and was but one influence on policymakers in 1935.

${ }^{20}$ Lebow, Between Peace and War, p. 102; Jervis, Perception and Misperception, p. 28.

${ }^{21}$ Hines H. Hall, III, 'The Foreign Policy-Making Process in Britain, 1934-1935, and the Origins of the Anglo-German Naval Agreement', Historical Journal, 19:2 (1976), p. 478.

22 Barbar, Who Makes British Foreign Policy?, pp. 64-5; Vital, British Foreign Policy, p. 48; Zara Steiner, 'Decision-Making in American and British Foreign Policy: An Open and Shut Case', Review of International Studies, 13:1 (1987), p. 16.

${ }_{23}$ Wallace, Foreign Policy Process, p. 113; Barbar, Who Makes British Foreign Policy?, p. 90.

24 Wallace, Foreign Policy Process, p. 88. See also, Barbar, Who Makes British Foreign Policy?, pp. 94, 97. 
By focusing on the key policymakers, the formal office holder perspective is more relevant to this period. It assumes the dominance of certain key ministers, particularly the Prime Minister and Foreign and Defence Secretaries, and holds that their goals determine policy outcomes. In line with Jervis's arguments, it emphasises the importance of their perceptions and experiences. ${ }^{25}$ During the crisis, Hoare acted as an originator of policy, rather than representative of the Cabinet (though the Foreign Secretary's relationship with the Prime Minister is crucial in determining his role). Contrary to Allison, this approach denigrates the role of civil servants because they lack the authority to act without ministerial approval. ${ }^{26}$ It has two main weaknesses. First, it relies too heavily on the disinterestedness of public opinion and other ministers. Whilst this may apply in more routine situations, it does not in relation to strategic dilemmas and other salient matters. ${ }^{27}$ Indeed, the Peace Ballot demonstrates public involvement, whilst the Cabinet was instrumental repudiating the Hoare-Laval Plan. The approach's second weakness lies in giving too little attention to how civil servants can exercise influence, if not formal power.

The departmental negotiated order perspective addresses this. Closely resembling the bureaucratic politics model, it emphasises the bargaining that occurs between departments. ${ }^{28}$ The Treasury's control over expenditure allowed it to wield the most influence over the Foreign Office, and its power peaked in the 1930s. ${ }^{29}$ Although the FO usually opposed external suggestions, crisis 'homogenises opinion and pulverises dissent', and can disturb established procedures, diminishing the relevance of bargaining. ${ }^{30}$ This departmental negotiated order approach also notes the important role played by civil servants. An official can impose his view on a department by force of personality, with some officials carrying more weight than ministers. ${ }^{31}$ Hugh Heclo and Aaron Wildavsky argue that 'officials will initially go along with an astonishing range of nonsense', yet the FO enjoys a reputation for imposing its views on its political chiefs. ${ }^{32}$ Though the assertion that 'the experts were on top, rather than on tap' goes too far, civil servants were very powerful in the 1930s. When structures became less controlling as in matters of high politics, they could exploit their personal relationships with ministers. ${ }^{33}$

The departmental negotiated order perspective is thus the most relevant in identifying the key actors in British foreign policymaking. The pluralist and public control perspectives both exaggerate the role of the public, while the formal office

${ }^{25}$ Barbar, Who Makes British Foreign Policy?, p. 18.

26 D. C. Watt, 'Divided Control of British Foreign Policy - Danger or Necessity?', Political Quarterly, 33:4 (1962), pp. 373-4; Wallace, Foreign Policy Process, p. 46; Steiner, 'Decision-Making', p. 3. See also, Barbar, Who Makes British Foreign Policy?, pp. 7-9.

27 Wallace, Foreign Policy Process, p. 13. See also, Barbar, Who Makes British Foreign Policy?, pp. 7-8, 22, 26.

28 Barbar, Who Makes British Foreign Policy?, pp. 34-5.

${ }^{29}$ Wallace, Foreign Policy Process, pp. 40-1; Vital, British Foreign Policy, pp. 57, 89; David Reynolds, Britannia Overruled: British Policy and World Power in the Twentieth Century, 2nd edition (Harlow: Longman, 2000), p. 45; Hugh Heclo and Aaron Wildavsky, The Private Government of Public Money: Community and Policy Inside British Politics, 2nd edition (London: Macmillan, 1981), p. 203.

${ }^{30}$ Peter Hennessy, Whitehall (London: Fontana, 1990), p. 78; Heclo and Wildavsky, Private Government, p. 162; Wallace, Foreign Policy Process, p. 74.

31 Barbar, Who Makes British Foreign Policy?, pp. 52, 60; Wallace, Foreign Policy Process, p. 10.

${ }^{32}$ Heclo and Wildavsky, Private Government, p. 379. See also, Ivor Jennings, Cabinet Government, 3rd edition (Cambridge: Cambridge University Press, 1959), p. 124.

33 Wallace, Foreign Policy Process, pp. 22, 51; J. A. Cross, Sir Samuel Hoare: A Political Biography (London: Cape, 1977), p. 188. 
holders approach understates the importance of officials. This conclusion needs to be qualified in two ways, however. First, much of the aforementioned literature appeared in the 1970s and thereafter. This creates problems in applying its arguments to a period during which FO officials had different attitudes and were more socially homogeneous and specialised. Moreover, insights from the other three schools are also valuable. Pressure groups and the public could affect the foreign policymaking process, but only at certain times. Even then, their influence was not decisive. It is also important to remember that political office holders, not civil servants, made the major decisions. Thus, to endorse the departmental negotiated order approach to identifying the most important actors in foreign policymaking is not, therefore, to support the claims of bureaucratic politics model in relation to the Abyssinian Crisis.

\section{Bureaucratic politics}

If the bureaucratic politics model is accurate in relation to the crisis, two features should be observable. First, the approach expects departmental interest to shape actors' views, with ministers sharing the opinions of their officials. Moreover, bargaining within the Cabinet should be apparent and the most powerful ministers should have their wishes translated into policy outcomes. In order to assess whether this was the case a number of groups need to be considered. Ambassadors could be expected to be sympathetic to their respective base countries, whilst the preferences of government ministries should follow their own particular interests. These ministries include the Foreign Office and its geographical departments, the Colonial Office, the Board of Trade and the Treasury. Finally, the military, and especially the Navy, also had one particular interest: the avoidance of overstretching their resources.

The two key British ambassadors tended to sympathise with their countries of residence. As the organisational processes model predicts, their dispatches shaped issues to further their causes. Sir Sydney Barton's telegrams from Addis Ababa demonstrate considerable backing for the Abyssinian cause. ${ }^{34}$ However, Barton's posting to a strategically unimportant country illustrates his relative lack of prestige within the Diplomatic Service. Although Hoare expressed confidence in him, there is little evidence that Barton's views influenced policy. Despite being a former League of Nations Secretary-General and holding a prime job at Rome, Sir Eric Drummond carried little more weight. The British Embassy in Italy wanted the tension to decrease, and Drummond showed some sympathy with Mussolini. However, instead of messages of confidence, Drummond complained more than once that the FO was not keeping him fully informed. ${ }^{35}$

34 See Barton to Simon, DBFP, XIV, No. 163 (19 February 1935); Barton to Simon, British Documents on Foreign Affairs [hereafter BDFA], Series G, Vol. XXVIII, Doc. 132 (20 February 1935); Barton to Simon, DBFP, XIV, No. 217 (26 March 1935); Barton to Hoare, BDFA, G, XXIX, Doc. 15 (30 June 1935).

${ }^{35}$ Hoare to Barton, DBFP, XIV, No. 474 (20 August 1935); Drummond to Hoare, BDFA, G, XXIX, Doc. 6 (I June 1935); Drummond to Vansittart, DBFP, XIV, No. 56 (22 December 1934); Drummond to Hoare, DBFP, XV, No. 60 (10 October 1935). 
There were similar position-influenced patterns in the relationships within and between government departments. The FO's Egyptian Department was concerned specifically about the impact on British prestige in Egypt and Sudan of an Italian conquest in Abyssinia and was more anti-Italian. ${ }^{36}$ Similarly, Vansittart admitted that the Colonial Office's 'local point of view' partly justified its hostility to Italy. ${ }^{37}$ On the economic side, President of the Board of Trade Walter Runciman opposed offering Italy access to Abyssinian raw materials and consistently resisted sanctions because of their negative impact on the British economy. ${ }^{38}$ The most influential department outside the Foreign Office, however, was the Treasury. Neville Chamberlain and his department's 'rigidly orthodox economic theories' guided the Government, and the state of the economy severely restricted the options available to policymakers. Moreover, although Vansittart fought his own corner, Chamberlain's abilities and standing enabled him to win support in Cabinet for his views. ${ }^{39}$ The Treasury thus exercised considerable influence over defence spending and compromise between the FO, Treasury and the service ministries contributed to the muddled nature of British policy.

While the Treasury's influence remained constant, that of military advisers increased as the crisis developed. They consistently opposed action against Italy. In the first instance, personal values played a part in this. The majority of generals and admirals were conservative. They admired Mussolini and were hostile to the League. ${ }^{40}$ Moreover, as the imposition of economic sanctions risked war with Italy and a quarrel with the US, the Navy's opposition 'was not surprising'. ${ }^{11}$ The Admiralty also had strong concerns about Germany as shown by their continuing pressure for the Anglo-German Naval Agreement (concluded on 18 June 1935), and were thus especially reluctant to contemplate action without French support. ${ }^{42}$ These views carried weight. The qualities of Sir Ernle Chatfield, the First Sea Lord, dwarfed those of his counterparts in the RAF and Army and his views on strategic matters were highly regarded. He dominated the Board of the Admiralty, including his political chief Sir Bolton Eyres-Monsell, the First Lord of the Admiralty. Eyres-Monsell's own naval background would have inclined him towards deference, whilst he enjoyed a longstanding friendship with the Prime Minister. Finally, although the Great War weakened the Navy, its glorious history still gave it a privileged position. Ultimately both Eyres-Monsell and the Air Minister, Sir Philip

${ }^{36}$ Memorandum by Campbell, DBFP, XIV, Appendix III (9 August 1935). See also, Barton to Hoare, BDFA, XXIX, Doc. 15; Draft memorandum by Jebb for the Dominions, J 3584/1/1, FO 371/19123, The National Archives, Kew, Richmond upon Thames, London [hereafter TNA] (2 August 1935).

37 Vansittart to Drummond, quoted in DBFP, XIV, No. 59 (28 December 1934), note 2.

38 Viscount Templewood, Nine Troubled Years (London, Collins 1954), p. 166; note by Oliphant, DBFP, XIV, No. 490 (20 August 1935); Chamberlain diary (29 November 1935), quoted in Iain Macleod, Neville Chamberlain (London: Muller, 1961), p. 188; Cross, Hoare, p. 236.

${ }^{39}$ Hall, 'Foreign Policy-Making Process', pp. 480, 484.

40 Taylor, Origins of the Second World War, p. 125.

${ }^{41}$ Keith Middlemas and John Barnes, Baldwin: A Biography (London: Weidenfeld and Nicolson, 1969), pp. 876-7.

42 Lord Vansittart, The Mist Procession: The Autobiography of Lord Vansittart (London: Hutchinson, 1958), p. 525, Hall, 'Foreign Policy-Making Process', pp. 477, 499; Frank Hardie, The Abyssinian Crisis (London: Batsford, 1974), p. 156; Chatfield to Vansittart, DBFP, XIV, No. 431 (8 August 1935); Chatfield to Fisher (25 August 1935), quoted in Arthur Marder, 'The Royal Navy and the Ethiopian Crisis', American Historical Review, $75: 5$ (1970), pp. 1330-1; R. A. C. Parker, 'Britain, France and the Abyssinian Crisis', English Historical Review, 89:361 (1974), p. 319. 
Cunliffe-Lister (created Viscount Swinton after the election), followed the opposition of their advisers. ${ }^{43}$ Minutes of the Cabinet and the Defence Policy Requirements Sub-Committee also highlight the salience of military and especially naval factors to decision-makers.

In 1935, the Foreign Office contained eight geographical departments, each with its own head. Above them in the hierarchy were four Assistant Under-Secretaries, and the Deputy and Permanent Under-Secretaries. Sir Robert Vansittart was the most influential official. He was 'a Germanophobe of the first water' and subjugated all else to the aim of preventing renewed German aggression. ${ }^{44}$ However, contrary to the bureaucratic politics model, there is little reason for his position to have influenced him in this way; it was simply his view that the greatest threat to British security emanated from across the North Sea. Vansittart exerted significant influence on both Hoare and his immediate predecessor as Foreign Secretary, Sir John Simon. ${ }^{45}$ Poor health adversely affected Hoare's judgement, whilst the divisions within the FO and Vansittart's own forceful personality also aided the Permanent Under-Secretary in getting his way. ${ }^{46}$ Preferring to focus on the threat posed by Germany, Vansittart opposed sanctions. His wish to 'buy off' Italy prevailed despite the opposition of Eden and other members of the FO and he instigated the Zeila proposals, which involved surrendering British territory to Italy as a means to a settlement. ${ }^{47}$ Vansittart's power peaked with the Hoare-Laval Pact, for which the press and Chancellor Neville Chamberlain held him responsible. ${ }^{48}$

There is evidence of bureaucratic politics within the Cabinet. The relative political standing of the two incumbents at the Foreign Office did make a difference to policymaking. Simon's prestige was low, but Hoare enjoyed the Cabinet's confidence. The Cabinet neither granted nor denied Hoare the authority to conclude the Paris agreement, but approved it nonetheless. Baldwin's lack of interest in foreign affairs as Prime Minister strengthened Hoare further and the 'inner' Cabinet (Baldwin, Ramsay MacDonald, Chamberlain, Simon, Hoare and Eden) took the decision to introduce sanctions, illustrating how prestige correlates with influence. However, the Foreign Secretary's perceptions and views were more important. This was especially so with Hoare, whose talents and experience at the

${ }^{43}$ Marder, 'Royal Navy', pp. 1336-7; Middlemas and Barnes, Baldwin, p. 553. Hardie, Abyssinian Crisis, pp. 150, 155; Cross, Hoare, p. 236.

${ }^{44}$ Hennessy, Whitehall, p. 85. See also, Jennings, Cabinet Government, p. 127.

${ }^{45}$ Earl of Avon, The Memoirs of the Rt. Hon. Sir Anthony Eden, Vol. II: Facing the Dictators (London, Cassell, 1962), p. 242; George W. Baer, Test Case: Italy, Ethiopia, and the League of Nations (Stanford: Hoover Institution Press, 1976), p. 147; Cross, Hoare, p. 201; David Dutton, Anthony Eden: A Life and Reputation (London: Arnold, 1997), p. 45; Middlemas and Barnes, Baldwin, p. 833; Rose, Vansittart, p. 164; Templewood, Nine Troubled Years, p. 138; D. R. Thorpe, Eden: The Life and Times of Anthony Eden, First Earl of Avon, 1897-1977 (London: Chatto and Windus, 2003), p. 157.

46 Avon, Facing the Dictators, p. 303; Cross, Hoare, p. 264. See also, Templewood, Nine Troubled Years, pp. 178, 191; Templewood, Nine Troubled Years, pp. 137-8.

${ }^{47}$ Note by Vansittart to Hoare and Eden, BDFP, XV, No. 251 (23 November 1935); minutes by O’Malley and Vansittart, J 2389/1/1, FO 371/19112, TNA (3 June 1965); Dutton, Anthony Eden, p. 47; Paul W. Doerr, British Foreign Policy, 1919-1939 (Manchester: Manchester University Press, 1998), pp. 181-3; Cross, Hoare, p. 204; Norton Medlicott, 'The Hoare-Laval Pact Reconsidered', in David Dilks (ed.), Retreat From Power: Studies in Britain's Foreign Policy of the Twentieth Century, Vol. 1: 1906-1939 (London: Macmillan, 1981), p. 126.

${ }^{48}$ Medlicott, 'Hoare-Laval Pact', pp. 124-5; Middlemas and Barnes, Baldwin, p. 892; Rose, Vansittart, p. 180 . 
India Office inclined him to work towards an administrative solution, whilst Vansittart pushed him towards appeasing Italy. Had Eden been Foreign Secretary, it is highly unlikely that he would have made a similar deal. ${ }^{49}$

Thus, personalities and perceptions of office holders emerge as being more influential on policy outcomes than their positions. This supports psychological approaches to FPA over the bureaucratic politics model. There is plenty of evidence that bureaucratic politics existed, but less that it affected outcomes. Ambassadors were sympathetic to their respective base countries, yet carried no real weight with decision-makers. The reactions of Foreign Office departments, the Colonial Office and the Board of Trade all tallied with expectations, but did not alter British policy either. The Treasury had more bearing. Vansittart also influenced policy, but his position did not shape his outlook. Similarly, whilst there was bargaining in the Cabinet, the personality, outlook and health of the Foreign Secretary were more important. However, the key place where the bureaucratic politics model falls down is in the case of the most powerful department, the Foreign Office. Departmental interest influenced Chatfield as First Sea Lord, but not Vansittart or Hoare. The Admiralty's goal was to ensure that the Royal Navy remained able to defend Britain and the Empire against external strategic threats. The Italian action against Abyssinia posed little direct danger to Britain, and the Admiralty was therefore reluctant to sacrifice ships to that cause. However, the role of the Foreign Office as a whole was to protect British security and interests. Eden considered that strong action against Italy via the League would best serve these interests; Vansittart and Hoare disagreed. This shows that departmental objectives do not always clearly prescribe action as Allison assumes. Individual actors must make decisions while trying to meet their targets. Nevertheless, the bureaucracy overall was generally unenthusiastic about action against Italy. Britain may well have stood aside were it not for the public outcry.

\section{Domestic politics and public opinion}

Domestic politics did more to influence decision-makers and policy outcomes than bureaucratic politics. In order to assess the full impact of these factors, two main tests must be applied. If the model is applicable, it needs to be shown that Parliament, comprised of elected representatives of the people, influenced policymaking. Closely linked to this are concerns about party politics. Second and most importantly, it is necessary to analyse how policymakers reacted to public opinion, especially on the key issues of the possibility of war, the League of Nations and the Hoare-Laval Plan itself. This is easier to ascertain than the impact of bureaucratic positions, as policymakers are more prone to refer to it in documents and Cabinet discussions. If the model holds true, alterations in the views of these two groups should correspond with policy changes.

49 James C. Robertson, 'The Origins of British Opposition to Mussolini over Abyssinia', Journal of British Studies, 9:1 (1969), p. 127; Avon, Facing the Dictators, p. 302; Middlemas and Barnes, Baldwin, pp. 871, 899; Parker, 'Britain, France and the Abyssinian Crisis', p. 318; Baer, Test Case, p. 48; D. Watts, Stanley Baldwin and the Search for Consensus (London: Hodder and Stoughton, 1996), p. 115; 'Conference of Ministers', CAB 23/82, TNA (21 August 1935). See also, Frankel, 'Towards a Decision-Making Model', p. 10. 
Parliament played a minor role in policymaking. Although Sir Robert Vansittart thought the mood to be generally anti-Italian, Parliamentary approval was unnecessary even for the application of sanctions. Parliament exerted itself more in opposition to the Hoare-Laval Plan. Opinion initially developed independently of public pressure, with former Foreign Secretary Austen Chamberlain and other senior figures opposing the agreement. However, Parliament's support was not required for the implementation of the Plan, and Foreign Office documents rarely refer to Parliament, citing it occasionally as an irritation. ${ }^{50}$ Backbench Conservative opinions were more salient. The Abyssinian issue exacerbated divisions within the Tory Party, with the die-hards opposing any sanctions against Italy whilst others favoured a particularly hard line. Fifty-nine Conservatives ultimately signed a motion of disapproval against the plan, and Daniel Waley and J. A. Cross both argue that the increased hostility towards Hoare in the House of Commons had more of an impact on the Prime Minister than did public opinion. However, while this did alarm the Government, it seldom appears in the documents. Furthermore, the Government's majority remained solid and, despite the acknowledged disquiet, Hoare's Parliamentary Private Secretary thought actual rebellion unlikely. ${ }^{51}$

Public opinion was more important. It initially gave conflicting messages to the Government however, illustrating a potential weakness with models that emphasise its power. When the people are divided approximately evenly, it becomes far more difficult to assess the public's impact. One action is bound to please one side, but that does not prove causation or even influence. In relation to Abyssinia, the evidence of pacifism restrained the Government, though its impact should not be over-stated. The famous pacifist victory in the East Fulham by-election of October 1933 had much to do with specific local circumstances and only Baldwin thought the result significant. Nevertheless, more than fifty peace organisations existed and there was little enthusiasm for war. The Cabinet thus opposed requests to mobilise the army or naval reservists out of fear for the public reaction. They also felt unable to give France a guarantee against any German reoccupation of the Rhineland despite the potential advantages to Anglo-French relations. As a Foreign Office official noted, public support was vital for any war. ${ }^{52}$

On the other hand, the commitment of the British people to the League was well-known. Ten million respondents to the Peace Ballot (released on 27 June 1935) supported economic sanctions against an aggressor - only 635,000 voted against -

${ }^{50}$ Marginal note by Vansittart, DBFP, XIV, No. 175 (25 February 1935); Vansittart to Hoare (10 July 1935), quoted in Parker, 'Britain, France and the Abyssinian Crisis', p. 298; Hoare to Clerk, $B D F A$, XXIX, Doc. 62 (25 October 1935); Daniel Waley, Public Opinion and the Abyssinian War, 1935-6 (London: Temple Smith, 1975), p. 68; James C. Robertson, 'The Hoare-Laval Plan', Journal of Contemporary History, 10:3 (1975), p. 453; minute by Thompson, J 2224/1/1, FO 371/19111, TNA (5 June 1935).

51 James C. Robertson, 'The British General Election of 1935', Journal of Contemporary History, 9:1 (1974), pp. 150, 152; Watts, Stanley Baldwin, p. 113; Waley, Public Opinion, pp. 68-9; Cross, Sir Samuel Hoare, p. 251; Parker, 'Britain, France and the Abyssinian Crisis', p. 323; Patrick to Hoare (12 December 1935), quoted in Cross, Sir Samuel Hoare, p. 250.

52 Doerr, British Foreign Policy, p. 163; D. C. Luckowitz, 'British Pacifists and Appeasement: The Peace Pledge Union', Journal of Contemporary History, 9:1 (1974), p. 115; CC 42 (35) 3, CAB 23/82 (22 August 1935); draft memorandum for the Dominions by Jebb, J 3584/1/1, FO 371/19123, TNA (2 August 1935). 
whilst 6.7 million also supported military intervention. ${ }^{53}$ The strong demand for British action against Italy was the greatest motivating factor in the Cabinet's decision to act. Hoare warned the Cabinet in August that any repudiation of League commitments would arouse public disquiet and based his sudden support for the League on political calculation. ${ }^{54}$ Throughout June, Vansittart repeatedly warned that the Government's fall could follow the destruction of the League. Ultimately, Hoare's argument that public opinion would desert the Government if it failed to support the League won over 'inner' Cabinet members who expressed doubts about introducing sanctions. ${ }^{55}$

The General Election demonstrates the effect of this strand of public opinion on decision-makers. Whilst aware that war would be unpopular, the Government was mindful that a weak sanctions policy would have led to accusations of betraying the League. ${ }^{56}$ Ministers knew that a tough line against Italy was a vote winner. The Defence Policy Requirements Sub-Committee was thus keen to avoid making any announcement about the possibility of détente with Italy until after the election. ${ }^{57}$ Leo Amery, a Conservative Cabinet Minister in the 1920 s, noted that it seemed evident the whole thing featured in [Baldwin's] mind as a useful aid to the General Election'. ${ }^{58}$ Although leaflets and speeches show that foreign policy was not the main issue during the campaign, the Prime Minister often emphasised the importance of the League. ${ }^{59}$ In this context, Hoare himself noted that electioneering in October and November 1935 'greatly complicated and hindered any detailed discussion of the Abyssinian negotiation'.60

This pro-League sentiment ultimately destroyed the Hoare-Laval Plan. Whilst the Cabinet approved the agreement on 9 December, the proposals were universally unpopular. ${ }^{61}$ The liberal establishment and most bishops were horrified. The public was 'indignant and ashamed'. ${ }^{62}$ There is little doubt that all this was responsible for the Government's change of heart. Chancellor Neville Chamberlain told Hoare that he doubted whether the Cabinet could maintain the agreement in the face of this opposition and at the Cabinet meeting on 18 December, Oliver Stanley, William Ormsby Gore and Secretary of State for the Colonies J. H. Thomas all referred to public opinion. ${ }^{63}$

${ }^{53}$ For the complete results of the Peace Ballot, see R. J. Q. Adams, British Politics and Foreign Policy in the Age of Appeasement, 1935-39 (Basingstoke: Macmillan, 1993), p. 161.

54 Avon, Facing the Dictators, pp. 237, 254; Cross, Sir Samuel Hoare, p. 212; P. M. H. Bell, The Origins of the Second World War in Europe (London: Longman, 1986); Dutton, Anthony Eden, p. 49. See also, Robertson, 'Origins of British Opposition', p. 122; Hoare to Chamberlain, DBFP, XIV, Appendix I(c) (18 August 1935).

55 Minute by Vansittart, DBFP, XIV, No. 301 (8 June 1935). See also, note by Vansittart to Hoare, DBFP, XIV, No. 308 (16 June 1935); minute by Vansittart, J 2459/1/1, FO 371/19113 (17 June 1935); CC 42 (35) 2, CAB 23/82, TNA (22 August 1935).

56 Doerr, British Foreign Policy, pp. 184-5.

57 See Parker, 'Britain, France and the Abyssinian Crisis', p. 311.

${ }^{58}$ L. S. Amery, My Political Life, Vol. III: The Unforgiving Years 1929-1940 (London: Hutchinson, 1955), p. 176.

${ }^{59}$ Robertson, 'British General Election', pp. 159-60; F. S. Northedge, The Troubled Giant: Britain Among the Great Powers, 1916-1939 (London: London School of Economics and Political Science 1966), p. 421; Amery, My Political Life, p. 180.

${ }^{60}$ Templewood, Nine Troubled Years, p. 176.

61 Amery, My Political Life, p. 183.

62 Avon, Facing the Dictators, p. 306. See also, G. M. Young, Stanley Baldwin (London: Hart-Davis, 1952), p. 217.

${ }^{63}$ Middlemas and Barnes, Baldwin, p. 891; CC 56 (35) 2, CAB 23/82, TNA (18 December 1935). 
These findings illustrate two key points. First, they reaffirm the limitations of Parliament in the sphere of international affairs. The Commons was divided and unable to wield any real power against the Government on foreign policy for procedural reasons, though the opposition within the Conservative Party to the Hoare-Laval Plan did worry the leadership. Moreover, the analysis demonstrates that the public is interested in major foreign events, and can have real influence upon them. Indeed, public opinion was the most salient domestic determinant of British policy. However, it also demonstrates the incoherence of public opinion. There was little understanding of the extent to which collective security involved international entanglements. ${ }^{64}$ The public wanted action against Italy, but, despite the Peace Ballot, it is questionable how many would have supported armed conflict with another Great Power over a slave-holding African nation, or would previously have backed tax rises for armaments. In short, the public wanted to support the League without paying the price. Ultimately, the anti-Italian sentiment pushed Britain to act and its influence can be seen clearly from decision-makers' conduct during the election campaign. Public opinion was also responsible for the Government's rejection of the Hoare-Laval Plan. However, the public was also unable to support specific policy decisions due to their lack of experience and the problem of government confidentiality. Thus, while the public played a major role in forcing Britain to act against Italy and in setting the parameters for her behaviour, it did not determine the detail of policy.

\section{Psychology, perception and rationality: the international dimension}

Policymakers' perceptions of the international scene were the main determinant of how they responded. Through scrutiny of the documentary evidence, it is possible to assess the origins and impact of these perceptions. If based on rational analysis, perceptions will be justified with reference to reasoned argument. Furthermore, the emphasis on the most influential decision-makers can be borrowed from the bureaucratic politics approach. If this model holds, policy outcomes should flow from their perceptions. Policymakers' assessments of the relevance of any historical analogies are the first to be analysed. Views of the League of Nations and Britain's role and reputation then need to be examined, but most important were policymakers' views of how other states would act. Of these states, the most significant were Germany, Japan, Italy and especially France.

The use of historical analogy by decision-makers was limited. They correctly rejected the analogy of the Anglo-Abyssinian clash of 1930. Nevertheless, Vansittart based the Zeila proposals on the nineteenth century practice of manipulating borders, whilst the failure of the League over Japan's invasion of Manchuria in September 1931 convinced Baldwin of the hopelessness operating sanctions against a first-class power. ${ }^{65}$ The most common analogy was the desire not to repeat the Great War. Personal experience was important here, as Eden,

${ }^{64}$ Donald S. Birn, 'The League of Nations Union and Collective Security', Journal of Contemporary History, 9:3 (1974), p. 132.

65 Drummond to Simon, DBFP, XIV, No. 66 (30 December 1934); Middlemas and Barnes, Baldwin, p. 836. 
who saw active service, took a very different view from those like Baldwin, Hoare and Simon, who did not. ${ }^{66}$ However, this analogy provided little prescription for action.

Views on the value of the League of Nations did prescribe. Eden was a genuine League supporter, but found himself in the minority. As Sir Eric Drummond, then League Secretary-General, wrote in 1931, 'the great majority [of the Government] are certainly not League men' ${ }^{67}$ Hoare's resignation speech indicated that a belief in the League's weaknesses influenced his thinking that only territorial concessions could save Abyssinian sovereignty. Duff Cooper, the freshly appointed successor to Viscount Halifax as Secretary of State for War, was also hostile, as were the service chiefs. This was especially true of Chatfield, the gifted and influential First Sea Lord. ${ }^{68}$ In the Foreign Office, ministers and officials regarded the League as just another tool, with Vansittart preferring 'the spirit of realism, on which our existence depends'. ${ }^{69}$ These views encouraged policymakers to look outside the League for a solution.

Yet perceptions of Britain's role and reputation had the opposite effect. R. I. Campbell wrote that any action undertaken with only France as an ally would damage Britain's reputation. Moreover, the failure to act against Japan over Manchuria increased the pressure to resist Italy and many in the Cabinet feared that imposing an unjust settlement on Abyssinia would, in Eden's words, 'rob us of our good name'. ${ }^{70}$ William Ormsby Gore, First Commissioner of Works but whose views on colonial matters Baldwin respected, stressed the potential imperial implications of such a blow to British prestige, whilst Halifax, an old friend of Baldwin who had recently become Lord Privy Seal, emphasised the Hoare-Laval Plan's danger to the moral standing of the Government and the Prime Minister personally. ${ }^{71}$ This was bound to influence Baldwin, who took pride in his trustworthy, 'man of the people' image.

Policymakers' perceptions combined with rational assessments of how they thought other states would act played the decisive part in their decision-making. The belief that US oil would continue to reach Italy rendered a complete embargo out of the question. ${ }^{72}$ However, the most salient perceptions related to British security. The widely held belief that Japan posed a danger to British interests had a significant impact. Baldwin's later comment that he could not put the League ahead of the Empire illustrates the weight he attributed to the Japanese factor, whilst the service ministries and the Treasury were especially keen to come to an agreement with Japan. ${ }^{73}$ Friendship with Italy was essential to Britain's position in the Far East, not least because passage through the Mediterranean was necessary to ensure supply lines.

${ }^{66}$ Reynolds, Britannia Overruled, p. 59; Thorpe, Eden, pp. 141-2.

${ }^{67}$ Drummond to R. Cecil (29 December 1931), quoted in Robertson, 'Origins of British Opposition', p. 133.

${ }^{68}$ Cross, Sir Samuel Hoare, pp. 205, 257-8; Duff Cooper, Old Men Forget: The Autobiography of Duff Cooper (Viscount Norwich) (London: Hart-Davis, 1953), p. 190; Marder, 'Royal Navy', p. 1341.

${ }^{69}$ Minute by Vansittart, DBFP, XIV, No. 175 (25 February 1935).

${ }^{70}$ Minute by Campbell, DBFP, XIV, No. 304 (12 June 1935); R. A. C. Parker, Chamberlain and Appeasement: British Policy and the Coming of the Second World War (Basingstoke: Macmillan, 1993), p. 47; Eden to Ormsby Gore (August 1935), quoted in Avon, Facing the Dictators, p. 249.

${ }^{71}$ Middlemas and Barnes, Baldwin, p. 855; Roy Jenkins, Baldwin, (London: Collins, 1987), p. 147.

72 Foreign Office paper (27 November 1935), cited in Cross, Sir Samuel Hoare, p. 235.

73 Middlemas and Barnes, Baldwin, p. 854. 
Whilst Japan threatened the Empire, an aggressive Germany could menace Europe and the British mainland. Indeed, Paul Doerr goes so far as to argue that 'Fear of Germany was the decisive determinant in British policy during the Ethiopian crisis'. ${ }^{74}$ The report from Sir Eric Phipps, British Ambassador at Berlin, on the accelerating German rearmament, which he thought would precede territorial expansion, epitomised British concerns. Compared to this, he said, the Abyssinian issue was 'mere child's play'. ${ }^{75}$ Similarly, Eden, Hoare, Chamberlain and Simon all prioritised European security. ${ }^{76}$ Two fears were paramount. The first was that Italian action against Abyssinia would weaken Italy, thereby threatening the balance of power and leaving Austria more vulnerable to Germany. ${ }^{77}$ Mussolini opposed the extension of German influence to Italy's northern frontier - hoping instead to install a pro-Italian fascist government in Vienna - and responded to an abortive coup by Austrian Nazis in July 1934 with a show of force on the border. ${ }^{78}$ More influential, however, was the view that British opposition to Mussolini would push him into the arms of German leader Adolf Hitler. This idea particularly animated Vansittart, and Hoare later justified the Paris plan with reference to it. $^{79}$

Those within the Cabinet 'who wanted to preserve Italian friendship at almost any cost' therefore opposed Eden. ${ }^{80}$ Simon preferred Italy to the League and feared the rise of Communism in the country should Mussolini fall. Although lower officials in the Foreign Office seemed to share Eden's view, Vansittart, again contradicting the bureaucratic politics perspective, did not. ${ }^{81}$ Whichever side they took however, few saw any possible gains from a conflict with Italy, even a successful one. Most of all, the Cabinet feared a surprise Italian attack against the British position in the eastern Mediterranean. Egypt, 'a jugular vein of imperial communications', and Malta were subjects of particular concern. ${ }^{82}$ Statesanctioned Italian press attacks on Britain motivated her partial naval mobilisation in September (cessation of these attacks was made a condition of détente) and an anxious Vansittart passed to the service chiefs Drummond's warnings from Rome that sanctions could precipitate such an attack. The First Lord of the Admiralty and others referred to intelligence reports that Italy planned to attack Britain. ${ }^{83}$ In

${ }^{74}$ Doerr, British Foreign Policy, p. 182. See also, Parker, 'Britain, France and the Abyssinian Crisis', pp. 331-2; Malcolm Smith, 'The Royal Air Force, Air Power and British Foreign Policy, 1932-37', Journal of Contemporary History, 10:3 (1977), p. 171.

75 Phipps to Hoare, DBFP, XV, No. 213 (13 November 1935).

${ }^{76}$ See Hoare to Drummond, BDFA, XXIX, Doc. 18 (6 July 1935); Record of Anglo-French conversation, DBFP, XIV, No. 553 (10 September 1935); Middlemas and Barnes, Baldwin, p. 855; Simon to Drummond, BDFA, XXVIII, Doc. 155 (3 May 1935).

${ }^{77}$ Hoare to Clerk, $B D F A$, XXIX, Doc. 23 (29 July 1935); draft memorandum by Jebb for the Dominions, J 3584/1/1, FO 371/19123, TNA (2 August 1935).

78 Robert Mallett, Mussolini and the Origins of the Second World War, 1933-1940 (Basingstoke: Palgrave Macmillan, 2003), pp. 21-4.

79 Drummond to Simon, BDFA, XXIX, Doc. 4 (23 May 1935); Simon to Barton, DBFP, XIV, No. 58 (26 December 1935); minute by Vansittart, DBFP, XIV, No. 175 (23 February 1935); Templewood, Nine Troubled Years, p. 185.

${ }^{80}$ Avon, Facing the Dictators, p. 36.

${ }^{81}$ Middlemas and Barnes, Baldwin, p. 830; A. L. Rowse, All Souls and Appeasement: A Contribution to Contemporary History (London: Macmillan, 1961), p. 26; J 2389/1/1, FO 371/19122, TNA.

${ }^{82}$ Steven Morewood, The British Defence of Egypt, 1935-1940: Conflict and Crisis in the Eastern Mediterranean (London: Frank Cass, 2005), p. 12.

${ }^{83}$ Morewood, British Defence of Egypt, pp. 27-8; Drummond to Hoare, J 5026/1/1, FO 371/19135 TNA (20 September 1935); Clerk to Hoare, DBFP, XV, No. 81 (15 October 1935); Robertson, 
short, the Government was aware that Mussolini would see an oil sanction as an act of war and Vansittart thus opposed it. ${ }^{84}$

Even though the Chiefs of Staff, Chatfield and Eden were confident of victory over Italy, there was widespread concern about Britain's preparedness for war. ${ }^{85}$ Italy had more submarines and a strong air force. At the Admiralty, Chatfield and Eyres-Monsell were particularly worried about the inadequacy of Britain's air defences. Vansittart pressed that Britain could not afford to lose any ships and the Chiefs of Staff advised against a naval war with Italy. ${ }^{86}$ Hoare attributed all Britain's failures to her military weakness, claiming that 'there was no effective support for our foreign policy', but even Baldwin thought his fear of war excessive. ${ }^{87}$ Nevertheless, several Cabinet ministers noted Britain's military weakness in August 1935. A Foreign Office official also identified Britain's military weakness as one of two key factors that influenced Hoare in making his agreement with Laval. The second was the French position. ${ }^{88}$

Given the potential threat from Germany and Italy, along with Britain's lack of preparedness, 'The Government concluded that everything depended on the attitude of France'. ${ }^{89}$ Baldwin conveyed to the Cabinet the importance of French support on 24 September. ${ }^{90}$ For the French, however, of paramount importance was the maintenance of the Stresa Front (of April 1935), an agreement between themselves, Britain and Italy to resist German rearmament. France even initially refused to guarantee to aid Britain against an Italian attack, though FO officials still believed that France would choose Britain over Italy if necessary. ${ }^{91}$ On sanctions, the French attitude was decisive. Having determined to impose sanctions on 9 October, the Cabinet decided five days later to postpone them until her ally's position was clear. They also decided not to exceed economic measures for the same reason. ${ }^{92}$

These findings suggest that perception and rationality proceeded in tandem. Decision-makers perceived certain actors to pose a threat to British interests, but this was born more from rational analysis. There was no evidence of groupthink and historical analogy played a very small part in British foreign policymaking, as there were few relevant analogies from which to choose. The impact of perceptions based on personal experience and beliefs was also limited. Most decision-makers shared perceptions of the League, and Britain's role and reputation, but these

'Origins of British Opposition', p. 142; Drummond to Hoare, BDFA, XXIX, Doc. 64 (30 October 1935); Middlemas and Barnes, Baldwin, p. 851; Parker, 'Britain, France and the Abyssinian Crisis', p. 312; Cross, Sir Samuel Hoare, p. 238.

84 Amery, My Political Life, p. 186; minute by Vansittart to Hoare, DBFP, XV, No. 323 (6 December 1935).

${ }^{85}$ Marder, 'Royal Navy', p. 1337; Avon, Facing the Dictators, pp. 244, 247.

86 Middlemas and Barnes, Baldwin, p. 850; Cross, Sir Samuel Hoare, pp. 223-4; Vansittart to Hoare, DBFP, XIV, No. 427 (7 August 1935); Medlicott, 'Hoare-Laval Pact', pp. 128-9.

${ }^{87}$ Templewood, Nine Troubled Years, p. 110; Middlemas and Barnes, Baldwin, p. 880.

${ }^{88}$ Cross, Sir Samuel Hoare, p. 211; Clerk to Hoare, DBFP, XV, No. 378 (15 December 1935).

${ }^{89}$ Avon, Facing the Dictators, p. 238. See also, Northedge, Troubled Giant, p. 412; Parker, Chamberlain and Appeasement, p. 102.

${ }^{90}$ CC 43 (35) 1, CAB 23/82, TNA (24 September 1935).

91 Clerk to Hoare, DBFP, XIV, No. 487 (22 August 1935); Parker, 'Britain, France and the Abyssinian Crisis', p. 308.

92 Medlicott, 'Hoare-Laval Pact', p. 129; CC 46 (35) 2, CAB 28/82, TNA (9 October 1935); Robertson, 'British General Election', p. 158; Record of Anglo-French conversation, DBFP, XIV, No. 554 (10 September 1935), Enclosure. 
produced contradictory impulses. Whilst unenthusiastic about the League, many felt obliged to support it to protect the Government's good name. Perceptions of how other states would act, formed largely by rational analysis, dominated. This is evident in the decision on oil sanctions, and in the influence of the fears of Japanese, German and Italian intentions, which provided the context. These perceptions counselled against strong action against Italy and coalesced with worries about Britain's military weakness. Perceptions of how France would act therefore became central to British decision-making. In her dispirited state, Britain had no wish to risk war or a weakening of her position without French support. Thus, reasoned judgement, as described by Hollis and Smith, took place without belief systems having a major noticeable effect.

This all questions Jervis's work when applied to a crisis situation. In such situations, policymakers are able to focus specifically on a particular issue. This was especially the case in relation to Abyssinia because the tension built up gradually. Views of security dominated and the fact that the fundamental goal, to uphold British security, was clear aided reasoned judgement. The evidence clearly shows that this consideration was paramount in the minds of most decisionmakers. However, rational analysis does not guarantee correct perceptions. Misperception can still occur, but perceptions based as much as possible on rational analysis are more likely to be accurate than those predominantly grounded in values and beliefs.

\section{Conclusion}

Addis Ababa fell on 5 May 1936. The discredited League swiftly rescinded the sanctions previously imposed on Italy, whilst British and French policymakers looked with increasing anxiety at Germany following the remilitarisation of the Rhineland in March. A number of factors influenced the British response to the Italian action. Bureaucratic politics did exist in the Government during the Abyssinian Crisis, but made little difference to policymaking. Office holders' personalities and views were more influential. More important still was domestic politics. The Government was concerned about backbench MPs, but attached greater significance to public opinion. With an election approaching, it was public sentiment that motivated the Government to support the League in a quarrel that had only limited relevance to British interests. The Cabinet sought to 'appease' Italy with the Hoare-Laval Plan once the election was over, but the public outcry prevented this. Public opinion thus pushed the Government to act. The perceptions of decision-makers inclined in the opposite direction. These views influenced the way in which Britain responded. Psychological influences were minimal and contradictory. Instead, judgements on how rival powers would act predominated. Decision-makers saw Japan and Germany as threats and this, alongside their belief in British weakness, made them reluctant to act against Italy, and insistent on French support if they had to. British policy resulted from the interaction between the public's desire for action against Italy and the wish of the majority of the Cabinet and senior officials to minimise the damage to Anglo-Italian and 
Anglo-French relations. This is contrary to A. J. P. Taylor's contention that British decision-makers 'did not know' why they acted as they did.

These findings provide an insight into the relative merits of the main FPA theories. The bureaucratic politics model is the least applicable. The Abyssinian case study highlights three of its shortcomings. First, it illustrates the problems of applying the model to the British policymaking system. The model holds that the preferences and operating procedures of individual departments influence outcomes, but the Foreign Office stood largely unchallenged in the making of foreign policy during the crisis. The Treasury set some limits by restricting expenditure, but had little influence beyond this. This left much less scope for departmental bargaining. It also shows that, as already mentioned, bureaucratic politics made little difference to outcomes even where it did exist. While these findings correlate with a convincing article by Edward Rhodes, the third relates specifically to crises. ${ }^{93}$ Because the Abyssinian issue was so important, the Government dealt with it at the highest levels. Existing organisational procedures ceased to be relevant, raising questions about the appropriateness of Allison's models to crises.

Domestic politics can have a major impact on foreign policy. This conclusion comes with three qualifications however, which those who argue for the primacy of domestic politics must address. First, the General Election increased the importance of public opinion markedly, and the fact that election pledges were still ringing in the electorate's ears influenced the rejection of the Hoare-Laval Plan. A Government halfway through its term could have reacted differently. Moreover, the Abyssinian Crisis commanded great public attention. The influence of the public is likely to be much less in more routine matters, in which are less interested. Finally, even when this interest was clear, it was contradictory and at most limited to making rather vague demands about outcomes. The public may articulate goals, but rarely will they instruct on reaching them.

This falls to decision-makers to resolve. The evidence presented suggests that in a crisis situation, decision-makers concern themselves with maximising the interests of their state more than personal ambition. Perceptions of how other states would act were uppermost in minds of decision-makers, but rational analysis more than personal experience or psychological factors formed these. This would further suggest that the rational actor model, despite its simplicity, retains strong explanatory power in a prolonged crisis. This is probably because decision-makers focus on the issue and have time to weigh up options. Greater convergence between the rational actor and psychological approaches is therefore required, along with further study of the conditions under which misperception is most likely to occur. Given the differences between states' systems and cultures, between values and circumstances over time, this is likely to vary. Thus, each foreign policy analysis approach provides insights into the Abyssinian case, but is insufficient alone to explain British policymaking. The greatest benefits are found in combining them.

93 See Rhodes, 'Do Bureaucratic Politics Matter?' 